\title{
Ireland and Spain 1931-1933. Divergent Republics
}

\author{
Alvaro Jaspe \\ University of Ulster
}

Copyright (c) 2011 by Alvaro Jaspe. This text may be archived and redistributed both in electronic form and in hard copy, provided that the author and journal are properly cited and no fee is charged for access.

\begin{abstract}
This paper will examine the development of the fledgling diplomatic ties between the new Irish state and the recently established Spanish legation based in Dublin. It will analyse the formal establishment of political, cultural and social links developed in contemporary times between the two old historical allies that had previously been limited to polite lip-service; conditioned, in part, as they were by monarchical Madrid's caution in regard to London and previous Spanish reluctance to engage with a rebellious state. 1931 signified a volte face in the relationship developing between Dublin and Madrid since the establishment of a Spanish consulate in Dublin in March 1924, facilitated by their commitment to the League of Nations, to which both were strongly committed in the 1920s. This paper will illustrate how the declaration of the II Republic in Spain was a crossroads in the relationship between these two nations. The roles of 'rebel' and 'traditionalist' state had been instantly switched. The Church and much of the new political elite in Ireland viewed republican reforms in Spain with ever growing and public distaste creating conflict among Irish republicanism, post-independence. The main Spanish republican representative in Ireland in this 1931-33 period, Emilio Sanz y Tovar, became very sensitive to these schisms as he tried to cement political and socioeconomic ties with his Irish hosts.
\end{abstract}

Key Words. Ireland, Spain, Second Republic, Republicanism, Diplomacy, Emilio Sanz y Tovar.

Resumen. Este artículo se propone examinar el desarrollo de los enlaces en ciernes entre el nuevo estado irlandés y el legado español recién establecido en Dublín. Tratará de examinar y analizar el establecimiento formal de lazos culturales, políticos y sociales en un contexto contemporáneo entre dos antiguos aliados que hasta aquella época bien se habían limitado a contactos de los dientes para fuera. Esto, en parte, se había debido a la cautela del régimen monárquico en Madrid en lo que se refiere a sus relaciones diplomáticas con Londres y el recelo por parte del estado monárquico español de asociarse plenamente con un estado rebelde. Sin embargo, 1931 representa un cambio significante entre las relaciones diplomáticas en vías de desarrollo entre Dublín y Madrid desde el establecimiento de un consulado español en Dublín en 1924, en buena parte facilitado por el respaldo y apoyo de ambos países en los años veinte hacia la Liga de Naciones. El ensayo describirá como la declaración de la Segunda República en España sirvió como una encrucijada en las relaciones entre Irlanda y España. El papel de estado 'rebelde’ y ‘tradicionalista' se cambiaron de noche a día. La Iglesia, y gran parte de la elite política en Irlanda, empezaron a ver las reformas republicanas en España con un creciente recelo, reflejado en la opinión pública irlandesa, que acabó creando un ambiente conflictivo dentro del seno del republicanismo pos-independentista irlandés. El ensayo examinará también el trabajo realizado por parte del representante diplomático español en Irlanda durante 1931-33, Emilio Sanz y Tovar, y sus esfuerzos por consolidar las relaciones políticas y socio-económicas entre Irlanda y España, en medio de las crecientes críticas de sus anfitriones.

Palabras clave. Irlanda, España, Segunda República, republicanismo, diplomacia, Emilio Sanz y Tovar 


\section{The Consulate in Dublin.}

By the end of 1930, the newly established (1927) Spanish consulate in Dublin, had developed a comfortable routine of diplomatic activity which included the writing of its annual report which revealed that at year's end, a total of nineteen Spaniards were residing in the Free State, whilst a further three were resident in the North (two in Derry and one in Garvagh. The majority of these nationals were students or members of religious orders, (6 each), domestic staff or chefs, the remaining number. Reports were compiled by Consul General Antonio Saque on matters such the difficulty of trade between the two nations given high Irish tariffs and the government subsidies received by the Irish tourist industry. One of the main events of the year for the Consulate was the move of its "cramped" offices in Westmoreland Street to more acceptable premises in Fitzwilliam Street Dublin (Archivo General de la Administración, Ministerio de Asuntos Exteriores, IDD no.39, 54/11726, reports of 2 and 31 December 1930). This was quickly followed by an "At Home" gathering held by the Consul at the Gresham Hotel which was attended by President Cosgrave and the Ministers of Finance and Foreign Affairs and several diplomatic representatives (Irish Times, 16-2-31).

Even into this diplomatic order there were signs that not everything back in Madrid was quite as mundane. Earlier on in February, Saque had received a direct instruction from the office of the Principal Secretary in Madrid to "play down any inflammatory or alarmist reports" on the situation in Spain which had recently appeared in sections of the Irish press (AGA Leg.14 C.54/11726 14-2-30). A view reinforced when five months later on 2 May he belatedly wrote to his new superiors in Madrid expressing his regret at not having contacted them earlier to express his support and loyalty to the new regime "given the uncertainty and disagreement of how to proceed in discussions with my colleagues dispersed around the world" After these initial doubts, Saque was taking the opportunity to "dispel any previous doubts" about his loyalty and sent his strongest expression of support for the new governmental institutions, who "as representative of the most genuine form of democracy, will allow Spain to discover the path toward prosperity” (AGA Leg 14 C.54/11726, 2-5-31).
This delayed response did not do enough to assuage the Spanish government's aim of appointing suitable and enthusiastic representatives to its diplomatic posts to defend the interests of the new Republic. (Egido Léon 2000: 191) So it was that by the summer of 1931 Saque was replaced by the more suitable Emilio Sanz y Tovar who by the beginning of August was reporting of the political instability in Ireland in the run up to the next general elections which were being undermined by "various secret societies condoned by the Catholic Church" which had survived President Cosgrave's "nine year repression." Despite that, his first impressions were that the country was "relatively strong" and that any change of government might allow "these societies to extend their influence.” (AGA, Leg 14 C.54/11726, 8-8-31)

The arrival of the new Consul to Dublin as representative of the new government in Madrid seemed to herald an era in SpanishIrish relations. The Foreign Ministry in Madrid, despite the difficulties of conducting a coherent foreign policy in the light of constant government changes (11 foreign ministers in 5 years) did, overall, seem more prepared to court the Irish Free State as a diplomatic ally and possible future trade partner. This period in Irish-Spanish relations was not marked by quite the same level of anxiety over whether to do so would be harmful to its relations with Britain, so typical of the period 1924-1930 (Jaspe 2008: 130). The Consular office in Dublin whilst also reflective of the changes occurring in Madrid, with four different occupants of the post in five years, each with differing attitudes towards the extremism of Irish Republicanism on the one hand or the conservatism of the Church on Irish society on the other, steadily pursued this overriding policy of developing diplomatic, business and cultural ties with Dublin. This paper focuses mainly on the tenure of Emilio Sanz y Tovar, 1931-1933, as Consul.

Tovar, recently appointed by the new Foreign Ministry in Madrid was particularly enthusiastic about his brief of developing ties with the Free State. To allow greater independence from the Embassy in London, one of his first proposals in August 1931 was to maintain the geographic unity of Ireland, in diplomatic terms at least, by arguing that the Derry and Belfast consular offices should be part of the same jurisdiction (AGA Leg 14 C. 
54/11726, 20-8-31). On 2 September he informed Madrid that whilst he had not officially presented his credentials to the Irish Minister McGilligan, he had been officially welcomed by the Joseph Walshe, head of the diplomatic service who assured him of "the Irish government's appreciation of this high ranking consular position” after talking at length about the good relations "that have always existed between our two countries." At this meeting Tovar had stated that Madrid's purpose in establishing and developing the diplomatic ties between the two nations was to "demonstrate its esteem and support for the Government of the Free State." To this end Tovar proposed that trade between the two countries should be developed beyond the existing level as well as the "spiritual and cultural bonds between them." Also discussed was the first official exchange of language students and teachers. Both parties agreed that they would do everything in their power to facilitate a strengthening of ties (AGA Leg 14 C.54/11726, 2-9-31). By the end of the year the cultural ball was well and truly rolling as in December the Spanish football team arrived to play return friendly at Dalymount, (Ireland had played in a 1-1 draw with Spain on 26 April) where despite a tour of the Guinness factory the day before, the visitors came out 05 winners (AGA Leg 14 C.54/11726, 5-12-31). The warm reception given to the II Republic's new representative by Joseph Walshe in many ways sums up his personal, and Ireland's, ambiguous response in 1931 to the political upheaval being experienced in Spain. A committed Catholic, and republican, he was convinced international Catholicism could play a vital role against mainly leftist totalitarianism in Europe. He followed the rightist movements in France and Spain with interest, in particular the career of José Maria Gil Robles, admiring as he did the CEDA's authoritarian politics mixed with Catholic social policy (Kennedy 2008: 191). The awareness of the strong historical ties between Spain and Ireland was something many fellow Irish shared and many, though by no means all, found it difficult to marry their own Catholic republican ideal with the secular, left leaning republican model taking shape on the Iberian peninsula. It was not so much a case that the establishment of the first attempt at twentieth century democracy in Spain passed Dublin by; it did not as official and public opinion will demonstrate. Arguably it is more accurate to state that they did not know how to respond to this similar, yet different form of Iberian republicanism.

\section{Irish responses to the Spanish II Republic.}

The main Irish daily newspapers reflected this dichotomy of opinion over the Spanish Second Republic and general interest in Spanish affairs. The influential Irish Times in particular regularly carried features on the political situation in the run up to and in the wake of the Municipal elections in April and of the consequences of their outcome. See Irish Times, "Boycotting the Elections", "New Powers for the Cortes" (9-2-31); "Opposing Forces Gaining”, "King May Surrender”, “The Future of Spain", (16-2-31); "Spain Again in the Melting Pot, the Spanish Crisis" (18-2-31); "King Alfonso's Future", "Football in Spain" (26-2-31). The latter concludes: "we must welcome this healthy keenness for Association Football among peoples who hitherto have devoted themselves to crueller sports as the bull-fight. In the present condition of Spanish affairs a football boom will be a blessing if it diverts the public mind from political abstractions."

In its editorial of 14 April the paper stated that:

The voice of the Spanish people has been heard for the first time in eight years, and its verdict is precise and clear ... urban Spain, in all its strongholds, endorses the Republican demands ... all the most active elements in Spanish democracy are willing, even eager, to welcome a Spanish Republic ... For the first time the impulses of democracy seem to have established a real hold upon south-eastern Europe ... They are in revolt against a long sway of costly and, one the whole, inefficient autocracy, which has varied between the corruptions of nominated cabinets and the severities of dictatorship. King Alfonso will be lucky if holds his throne; certainly he must resign himself to a drastic curtailment of its privileges (Irish Times, 14-431).

Opinion elsewhere in the Irish press and society as a whole, if not quite as outspoken in favour of the new Republic, wavered between praise for having broken with the monarchical institution and recognising nationalist aspirations in Catalonia, tempered with a fear for the future of the Church and the Catholic Monarch, reflecting the political ambivalence toward this movement within Ireland.

The Irish Independent initially seemed to 
endorse the opinion of the majority of Spain in favour of the Republic (15-4-31) whilst the Sunday Independent chose to analyse the increased power of Catalonia in the new Republic stating: "From being the 'bad girl' of the family of the Monarchy, Catalonia has changed its role, and is now the strong child of the new Republic.” In a full page report on the role of the region, "which has almost succeeded in imposing its terms of regional independence upon the Central Government of Madrid" the paper concluded "All relics of the Monarchy will be removed in time, and it is the strong opinion of everybody that the King has gone forever" (Sunday Independent, 19-431). This struck a chord with the concept of a national identity asserting its independence against an overbearing imperial master, but a note of caution still prevailed, even here. The Vatican's failure to formally recognise the new regime in Spain was noted (Sunday Independent, 19-4-31).

This emotional conflict was also evident in regional titles. For example on 25 April the Connacht Tribune reported that with Alfonso XIII's departure, "a resounding blow was struck for a Republic" but three weeks later emphasised the civic breakdown surrounding the sacking of religious buildings and the departure of the Spanish Primate from Spain (16-5-31). For its part, in the Cork based Southern Star the columnist, Finnerty, though acknowledging the "recent peaceful revolution in Spain" felt that "general sympathy is felt with his Most Catholic Majesty Alfonso who has suffered for the misdeeds of others" before reminding his readers of the historical ties between Irish Catholic history and Spain (254-31). The Anglo Celt sympathised with the "badly advised" departing monarch who did so "in the interests of his country" (18-4-31).

Even the Irish Times in its April editorial "A King Departs" lamented the loss of "Spain's most gifted, most experienced and most resourceful man of affairs" going into exile, noting with alarm that with Catalan proclamations of independence, "the shadow of a Spanish Ulster looms on the horizon of the Spanish Free State" (15-4-31). The impact on the relationship between the Vatican and Republican Spain was itself the subject of another editorial two days later where it was noted that the nation's new rulers were still Catholic, "The coming conflict - or reconciliation-between political liberalism and religious conservatism may furnish a deeply interesting chapter in the nation's history" (Irish Times, 17-4-31). As such the observations and comments regarding the events in Republican Spain were the equivalent of holding a mirror to the political divisions that still prevailed within Ireland in the wake of Independence and Civil War: of support on the one hand, and fear and suspicion on the other, in the break with the old established order and the uncertainty of what would follow.

The letters from the public on the subject of Spain seemed to reflect this schizophrenia of opinion. In a letter to the editor of the Irish Times, E.T. Keane of Kilkenny argued that in "the hour of adversity of the patriot King of Spain" that it would be "a graceful and generous gesture on the part of the Government of Saorstat Eireann to extend to him an official hand and cordial invitation to make their future home in Ireland" given the "time-honoured links uniting Ireland to Spain." He did not feel that this stay would be for long given the certainty, "that sooner or later ,when the Spanish people are thoroughly fed up with the bunch of adventurers, anarchists, atheists and doctrinaire professors who have engineered the revolution, King Alfonso will be recalled to the throne" (Irish Times, 18-431). The public support generated by this campaign to bring Alfonso to Ireland resulted in none other than the President of the Executive Council, Cosgrave, having to publicly announce that "whilst he would be honoured if the King did come here, there was no question of inviting him for the simple reason that there is no place available which would afford suitable accommodation.” It was emphasised that this was the "only reason" preventing such an offer. Cosgrave understood why some of his countrymen were proposing such a move given that "the Spanish people had always been good friends of Ireland" (Irish Times, 20-4-31).

Other letters such as the one from the anonymous 'queremos saber' (we want to know) of County Wicklow challenged the view "accepted universally in the press of this country that the anti-Monarchists in Spain secured an overwhelming victory in the recent municipal elections in the country" when more monarchist than republican councillors were returned (predating Pío Moa by 70 years). The debate was continued the following day in the letters when 'El bachiller Sanson' (Sanson 
the graduate) replied that the difference in size between the municipalities was the key to the victory adding “The Provisional Government probably never realised the perplexity that might arise in honest minds abroad" (Irish Times, 24 and 25 April 1931 - Sanson, was in fact Dr.Walter Starkie, the first professor of Spanish at Trinity).

In the Irish Independent, a Bradley McCall wrote from Barcelona giving his analysis of events in Spain where the "cunning and elegance of the Bourbon" Alfonso had made "one mistake, and that a fatal one, his treatment of Catalonia." These "thrifty and business like people" had been promised "home rule - the price of their importance." Failure to deliver by Primo de Rivera and the King had cost both dear, which within the Irish context could be seen as leave the North well alone. Spain under the "most devout Catholic" Alcala Zamora stood a chance, but Mr McCall was convinced that ultimately "Russia will have a say" and that the Communists would remain "strong" (Irish Independent, 26-5-31). Such evidence would once more suggest that Irish attitudes to events in Spain quite accurately reflected the post civil war tensions prevalent in 1930s Ireland whereby the conservative incumbent Cumann na Gaedhal government of William Cosgrave, advocate of the Free State status quo viewed the increasingly republican stance of de Valera's Fianna Fáil and its courting of IRA, as anti-Catholic revolutionary radicalism. This division gradually extended to the interpretation of events in Spain in April 1931 which, when viewed from the Irish perspective, were seen very much along the anti-Catholic or revolutionary/republican lines with Catalonia often cast in the role of Northern Ireland. What part republicanism would play in the new state was at the forefront of the 1932 and 1933 elections and it was quite natural that many Irishmen's interest in Spanish events reflected the political tensions within their own domestic political situation.

The initial reforms of the Provisional Government, in particular those pertaining to the Church, and the Spanish elections of June 1931 were thus avidly followed from the pages of the Irish newspapers. The Irish Times devoted most column inches, and greatest editorial comment to the legal, constitutional issues regarding the emergence of the new Republic and its new constitution, again with obvious domestic overtones. See Irish Times articles "The Spanish Republic" (27-5-31); "The Spanish Elections" (24-6-31 and 29-631); “The New Cortes” (14-7-31); “Spain's Troubles" (23-7-31); "Spain and Catalonia” (58-31); "Conflict in Spain" (26-8-31). Over the disputes regarding the drawing up of the new constitution it proclaimed in its editorial of 18 August, "The New Spain" that the new document "has little to recommend it. Indeed, its sole merit, perhaps, is its insistence that Spain be a unitary State, although the extent of autonomy yielded - especially to Cataloniadoes much to abate this virtue.” Its leader was taken aback by the sweeping social and religious reforms that had been enshrined by the new document, focussing particularly on the dissolution of the religious orders and the introduction of divorce. Even the most mainstream lay newspaper Ireland blanched at the complete break between State and Church concluding in the same editorial that "we cannot visualise Roman Catholic Spain in a virtually pagan trough” (Irish Times, 18-8-31). The Irish Independent very quickly abandoned its neutral, wait and see stance, and became increasingly anti-Spanish Republican as it focussed more exclusively on the social reforms and distancing between Church and State, though it continued its support for the policies which favoured Catalan autonomy, again mirroring the divisions in Ireland for and against partition and Home Rule. In so doing the paper remained true to its anti-Parnell, Home Rule origins of the early century.(ProCatalan articles see Irish Independent - Spain and Catalonia, 2-5-31; Catalan Home Rule, 58-31) The anti-Catholic, Communist nature of the Spanish Republic was expounded at length in articles entitled "Spain and the Soviet", of 16 October, "Communism in Spain of 20 October or "Pope's Sorrow for Spain" where it was now clear that "Spain, after her good and heroic past, has allied herself with the persecutors of Faith.”( Irish Independent, 2210-31) In November the article "How Moscow's agents are working in Spain" made it clear that the recently passed Constitution was an example of how the "middle class Revolution in Spain under Zamora" would witness, like Kerensky in Russia in 1917 the " ... setting up of a Peasant and Workers Republic, controlled by the same (Soviet) powers" (Irish Independent, 11-11-31). This difference between types of republic needed to be made clear to Independent's moderately 
nationalist, unswervingly Catholic readership. After all, on the one hand, he was being convinced by some in the autumn of 1931 of the appropriateness of a republican political settlement for Ireland, just not of the Spanish type. In its 16 October "Spain and the Soviet" leader the Independent accused the Azaña Government of trying to introduce "the doubtful blessings of a Red Republic" but that this "Red republicanism" would not find a lasting home in Spain "whose Catholicity has stood the test of centuries ... any more than it would amongst the Catholic people of Ireland.” As such a Catholic, green republicanism was fine for Ireland, not the red, socialist brand erroneously chosen by Spain.

A similarly ambiguous view was taken by the recently established Irish Press, with strong Fianna Fail connections. Its first edition on 5 September 1931 carried an article on the role being played by Catholic working women in Barcelona, trying to persuade their husbands to abandon their anarchist inspired strikes. Initial reports on Spain followed in this vein of praising the nationalist, conservative, elements of the Republican movement in Spain, but observing a far more reserved attitude to the anti-clerical leaning of the reforms, especially with regard to the Church.

On 10 September 1931 it published an article by Jaume Ruiz Manent entitled "Catalonia's struggle for freedom.” This warned the Irish Press readers that Catalonia's nationalist aspirations were being endangered "by the peril of anarchism." The paper promised that it would continue representing "Ireland's interest in the struggles of other peoples for national freedom" but felt a special bond with Catalonia where, like Ireland, language and history were "a symbol of the revival of the nation" (Irish Press, 10-9-31). The initial favourable attitude to the Republic in Spain seemed to be reinforced by close informal links between the Irish and Spanish political elites as evidenced in a series of four articles sent back from Spain by Michael Lennon in September 1931 which started with an interview with Victoria Kent, first woman barrister in Spain and socialist Spanish minister of prisons within the Justice department in the provisional government. Her Irish credentials, "kinswoman of Thomas Kent” the Cork IRA Commander executed in 1916 according to the report, were almost as impressive as her career. Lennon commented that he had expected to see "the
Irish name to pass from public life in Spain” so closely associated were they with the outgoing Crown. Her presence, it was suggested, was a symbol of the moderation which still prevailed within the administration. The article prompted the first editorial comment entitled "Truth from Spain” where although it was admitted that many Irish men and women found themselves to be "perplexed" regarding events in Spain, it was felt:

We in Ireland, hereditary friends of Spain, have nothing to say, touching on the Spanish people's repudiation of the monarchy, save that we wish them happiness under the new regime. It is not for us to judge whether their decision is wise; but we may say this, that is simply evident that the old order brought its fate upon its own head by neglect of the people's grievances and hostility to reform. We watch anxiously lest the flood of change should carry away good things as well as bad (Irish Press, 15-9-31).

True to its promise to base their and Irish opinion on the words of the Republican leaders in Spain, "rather than on partisan reports" the following day's title carried an interview with none other than Minister of Justice, Julian Besteiro entitled "Future of Catholic Church in Spain.” Lennon was critical of Besteiro's and other ministers "Republican credentials" but welcomed the minister's comments where he played down the disestablishment of the Church but emphasised the need for "a new Concordat with Rome." His rejection of mob violence against Church property and enthusiasm for a "negotiated settlement" with the ecclesiastical hierarchy obviously struck a chord with Lennon and the Irish Press leader, the latter very keen to emphasise that it was the first title in Europe to publish Besteiro's policy toward the Church in full (16-9-31). In the third report from Spain, after attending a session in the Spanish assembly, Lennon had seemed to have sympathised at least with the Republican authorities in Spain. The attacks on the Church were symptomatic the blame of "Spanish Catholic Aristocracy" who in opposing social reform and Catalonia's struggle for independence had allied the Church with "disedifying types whose wealth offends and goes against natural justice.” To support his claim he quoted one of Besteiro's assistants, a Father Posada, who stated that now at least the clergy were "free to speak" unlike before, implying a certain sympathy for the sister Republic in Spain (Irish Press, 17-9-31). 
A series of articles favourable to Spain and its anti-monarchical government appeared over the next few weeks, including practical shopping advice for Irish travellers in the country (Irish Press, 23-9-31, 24-9-31, 2-1031, 5-10-, 31, 6-10-31). This attitude was not one that prevailed. Already on 15 October the paper noted with dissatisfaction in its editorial, "Ungrateful Avila" that the "fanatical" municipal authorities there were removing St. Teresa de Avila's name, "curiously like an Irishwoman in her spirituality", from all street signs. The news of the Constitutional attack on the religious orders meant that the Irish Press became almost as critical of the II Republic as the Irish Independent. The reports and editorial comments made on Spain between October and December 1931 (see Irish Press 16, 17, 21, 22, 26, 27 October; 4, 6, 18, 24 November; 2, 12, 10, 11, 12, 14, 15 and 16 December) meant that the Irish Press whilst welcoming social reform and local autonomy for Catalonia," could not reconcile itself with what was ultimately, in its view, an "unchristian constitution" (9-12-31). It too tried to distinguish between green, religious, Irish republicanism and the red, heathen Spanish variant by noting that in Spain, "the Communist element gained the upper hand so quickly” because Spain was only superficially Catholic, unlike Ireland, "where the people support the Church." Again criticism of the Spanish ecclesiastical authorities was implied because of their "apathy and ignorance" in allowing events to unfurl.

\section{Consul Tovar : Irish perceptions of Spain / Madrid's view of Irish politics 1931-33}

Consul Tovar was very aware of these divisions in Irish politics as his reports to Madrid in the run up to the February 1932 elections testify. He was also particularly attuned to the continuing sniping that developed from sections of the Catholic press against the Republican government in Madrid as the view of Spain's new administration conforming to anti-Catholic republicanism took hold. In January 1932 he still believed that de Valera's republican Fianna Fáil party would lose out to Cosgrave's government because of the "cuestión batallona" (key issue) of the Free State's standing with Britain, particularly with regards to the economy which he felt de Valera's radical policies would harm.
On 2 February he wrote that the elections of 16 February would decide "if the country wants to continue along present lines or, if on the other hand, it wishes to discover new economic and political solutions.” A de Valera victory would end the Free State and see Ireland emerging as a state "almost totally independent from England." Rumours of the creation of a united Ireland were circulating around Dublin but Tovar seriously doubted that the people of the north "nearly all Protestant and of Scottish descent" would agree to such a union. Problems regarding the currency, the role of Irish civil servants, the impact on agriculture were all factors that Tovar believed would "sweeten many of the radical and extremist" policies of de Valera who he was now convinced would narrowly emerge triumphant (2-2-31). On 22 February Tovar gave a detailed breakdown of the Fianna Fáil victory stating that Cosgrave lost the election through complacency and because he was too overtly anglophile. Ireland would now become a republic and the Oath of Allegiance sworn by Dail representatives would also be removed, with wide sweeping effects on Ireland's relationship with Britain. Tovar commented that de Valera would promise the minority Labour party all sorts of concessions regarding "dangerous economic experiments such as nationalization of banks, industry and trade" in order to "get his hands on the reigns of power" but that they would be diluted once that had been achieved (22-2-32).

Away from the political changes in Ireland Tovar gave an update on the work being down by the Consul to promote Spanish language and culture in Ireland. The former had not grown considerably given the "obstacles toward language learning, so typical in English speaking countries” (AGA, Leg 14 C.54/11727, 9-3-32). Spanish at Trinity College was growing under the tutelage of Dr. Walter Starkie, the recipient of the Order of Alfonso XII in 1928 and also at University College under Professor Maria Degani. Other "less important" institutions were also teaching Spanish but it was the first official 'teacher/student exchange' organised by the nuns of the Sacred Heart of Mount Anville in Dundrum that particularly caught the Consul's eye. They had established a system of bringing over wealthy and educated young women from Spain "señoritas de buena sociedad" (ladies of 
good standing) who were given the opportunity to learn English and be put up for free in the school in return for giving Spanish classes to the students. "They tend to stay for a couple of years and are free to come and go as they please, even being allowed to accept invitations away to the country in the company of distinguished families.” (Ms Emilia Ubeda of Madrid and Constancia Monsalve were the most recent graduates of the scheme). No Spanish organisations or publications existed as yet and there were no Spanish religious orders despite the presence of Spanish seminaries in Dublin amongst the Jesuits and other orders (AGA, Leg 14 C.54/11727, 9-332).

After analysing Fianna Fáil's narrow victory and their dependence on the support of the Irish Labour Party Tovar concluded that he was not sure what to make of de Valera himself who he described as "appearing to be influenced in his policies by a type of mystic sentimentality." The economic war that would result with Britain might accrue some benefit to Spanish trade (AGA 11726, 18-3-32). Indeed, four days after that report Permanent Secretary Walshe visited Tovar in the Spanish Consulate and discussed "a preferential trade agreement between Spain and the Free State." Unlike previous negotiations in the 20's when the Consulate was established, Walshe wanted any future discussion regarding this matter of mutual interest to go exclusively through the Dublin Consulate as the possible intervention of the Spanish Embassy in London would go against the principles defended by the current Irish Government” (AGA 11726, 22-3-32). Whilst the de Valera was looking for new friends, the government in Madrid exercised caution, not wanting to damage their own economic dependency on British investments further.

As the first anniversary of the Second Republic approached the continued criticism from Irish sources of the Republic in Madrid, and the significant influence these had in European and particularly US Catholic circles, meant that Tovar was directly instructed by the Ministry in Madrid in March 1932 to quell articles critical "of the change of regime in Spain" and instead "influence opinion so that the advantages of the new institutions and national and political progress" were more widely known. He was to also ensure that the mainly religious, "Spanish colony resident in
Ireland" keep their public commentaries favourable to the government. Tovar replied on 19 March that he would "with all conscientiousness and effort" attempt to counter "all references that are critical of our Motherland and transform any hostility or indifference into appreciation for Spain and the Republic” (AGA, 19-3-32). This task alone would become more or less a full time job as references to Spain in the Irish press generally became more vocal in their criticisms as 1932 progressed.

The Irish Independent dedicated no less than five editorials and dozens of articles in the four months up to the Republic's first anniversary chronicling in detail the descent, in its view, into chaos and bloodshed being unleashed by Communism, accurately reflecting the mood among ecclesiastical circles in Ireland to the Godless events unfurling in the once most Catholic of nations. [For a flavour of the antiRepublican discourse see the Irish Independent articles "Bloodshed in Spain" (20-1-32); "Chaos in Spain" (21-1-32); "Bomb fights in Spain” (16-2-32); “Republican Spain's war on the Jesuits" (17-2-32); "Bomb outrages in Spain" (24-2-32); "Save Spain from Communism” (3-3-32); "Tyranny in Spain” (93-32); "Irish prayers for Spain” (23-3-32); "Menace of Communism in Spain" (22-4-32)]. The Bishop of Derry, Dr. O’Kane, in his open Lenten Pastoral exclusively dedicated to Spain of 8 February commented, "The revolt from the Church in Spain seems to have brought great joy to a certain class in the North of Ireland, who seem to see in it a sign of the determination of its people to shake off an intolerable yoke.” Rather, in his opinion, “The sight of a great Catholic nation wavering in its allegiance to Christ should fill them with fear and misgiving” (“Dr. O’Kane and Spain”, Irish Independent, 8-2-32). In his letter of 21 March publicising the hosting of the Eucharistic Congress Committee in Ireland later in June, Reverend Maurice O'Connor of Listowel commented that at present "tyrants worse than Mussolini are persecuting our fellow Catholics in Spain." The Congress would be an opportunity for Ireland to "unsheathe the Spiritual Sword" against this process (21-232). The Prelate of Spain, Frutos Valiente, beseeched the Irish patron Saint himself at a ceremony in the Irish College in Salamanca playing on Spanish and Irish unity to "intercede for Spain in this her hour of trial ... 
Ireland say a prayer for Spain" ("Irish prayers for Spain”, Irish Independent, 23-3-32).

The editorials criticised Spanish foreign policy, for example, in its relationship with Portugal, "Spain at the moment has nothing to offer to any other country, and least of all to her neighbour" ("Spain and Portugal”, 11-132). Fiscal and trade union policy was severely questioned on 16 and 23 February, in 'Troubles in Spain' and the 'The Spanish Budget' respectively. Conflict between the government and the workers' groups was natural among "men who indulge in sacrilege." Whilst the Spanish coffers may have been freed of its ecclesiastical and royal household payments, "this saving has been more than offset by an increase in expenditure on the salaries of deputies and the President" completely replicating verbatim the rhetoric of Catholic owned papers in Spain. In its piece, Communist Menace again the weak Republican government was portrayed as a sop to the "high priests of Red bolshevism." In its "Spain Sick of Republicanism" editorial of 9 February it warned "Azaña's Government appears to be powerless in the face of the growing chaos, bloody disorder, and acute distress which, so far, have been the principal fruits of the Republican regime in Spain" (Irish Independent, 9-2-32). Again, making the distinction between red and Irish republicanism, on 16 March the paper comforted those readers worried where de Valera's republican vision might be taking them with the assuring headline, "Ireland will not follow Spain and go Communist and Socialist ... in Ireland the priests and the people had been driven closer together by persecution." That was the conclusion of Reverend A. Gwynn at the conference on Church and State in Modern Spain held at UCD. The Spanish priest present, Father Balagner (Balaguer) assured the Irish audience that "the Catholic Party would eventually triumph through Constitutional means" and that the recent Jesuit expulsion was due to "the anti-Catholic teachings of the State Schools" (16-3-32).

This was exactly the type of anti-Republican rallies and sentiments that Tovar had been instructed to counter, and to which he had been very deliberately not invited. As part of his new remit on 12 April he informed Madrid that he had written to Balaguer asking him to make an appointment at the Consular offices where the Jesuit defended his participation and the conference by stating that it was untrue that "the argument put about here that the Spanish Republic is anti-Catholic is not true as it is well known that in the last municipal elections many Catholics voted for the Republic." Furthermore Balaguer assured Tovar that no attacks had been directed at the Republic or toward Spain.” Tovar sought assurances that Balaguer would refrain in future "from participating in events or conferences in which there are firm reasons to believe that new attacks will be launched against our country or government” (AGA, 12-4-32).

With regards to the Independent, the Spanish Consul appears to have more or less given up trying to get it to change its anti-Spanish Republican stance, but not with the Irish Times and the newly created Irish Press. When the Times, the most important paper in the country, published on 1 April an editorial 'Unrest in Spain' arguing the situation there was not "as desperate as it often made out to be" but that Spain had no towering statesman-like figure "like Hindenburg or a Mussolini" to fill the void left by Alfonso XIII. It is somewhat ironic that Tovar should have felt compelled to visit the editor of the one newspaper that was attempting to give a something resembling a balanced account of events in the peninsula by visiting the Times' editor, Robert Smyllie and reproaching him "for the monarchist tendency of his article." Tovar lectured him on the fact that in Spain there were "many capable men able to govern but not in a personal or authoritarian style but with the co-operation of Parliament" Smyllie was then given a brief resume of Spain's role in promoting peace under the auspices of the League of Nations, combined with a brief outline of Madrid's official policy regarding disarmament. Smyllie apologised to the Consul for the offending piece stating "that in reality they know very little about Spanish political problems. Any future articles on Spain and the Republic will be more balanced" (AGA, 12-4-32).

The Irish Press was also prolific in its reports on Spain during this period although here a faint distinction was attempted to distinguish between the good, nationalist Spanish (Catalan/Basque) republican and the bad anti-clerical, Masonic influenced one. The attitude of Cosgrave's government in being one of the first to recognise the II Republic even became a minor election issue at the 
hustings in Coolock where it was criticised by the Fianna Fail candidate, Sean MacEntee, of "standing by" as the Church came under attack in Spain (Irish Press, 13-2-31). Following this incident, a member of the Kent family wrote to the paper on 30 March 1932 to publicly distance his family from the Victoria Kent in Spain, "recipient of an appreciative article by the Irish Press." All ties with the Kents in Castlelyons in Cork were repudiated with the proviso, "even if it were true, the manner in which this lady has treated Catholics in Spain would have the effect of every member of the Rice-Kent family disowning her" (Irish Press, 30-3-32).

The Consul was eventually obliged to intervene with regards to the Irish Press and its reports on Spain when on 5 April it published the editorial 'A blow from a friend' in which it accused the Madrid government "so blinded by its hostilities to Catalan aspirations" to happily standby and witness "Ireland being deprived of its rights forever." The paper was responding to an article that had appeared in El Debate on Ireland which had not made the distinction between green/Catholic and red/Spanish republicanism in its critical piece on the political situation in Ireland. The article concluded the Spanish people were only being allowed to hear the "British side of the argument” with regards to Eire (Irish Press, 54-32). Given the direct and very obvious links with the new Fianna Fáil government, de Valera was its controlling director, such an opinion could be seen as reflective of opinion at the highest level of Irish political life (Horgan, 2001: 22). The Consul wrote to the editor of the Press stating his surprise that the paper could believe "the Government in Madrid was hostile to the aspirations of Catalonia and by extension the nationalist cause in Ireland," when it was currently working on the Statute of Autonomy for "this Spanish region ... which will permit of a certain autonomy within the bounds of national unity." He took the opportunity to clearly state that "not only are Spanish sentiments towards Ireland not hostile but, on the contrary, they are sentiments of affection and esteem" (AGA, 194-32. Letter appeared in the Irish Press on 184-32).

Tovar prematurely assumed that a social contact with the editor of the Independent had secured a change in the unrelenting criticism of Spain when on 3 May an article entitled "New
Constitution" appeared in which a "well informed correspondent," that is, the Consul himself, wrote a glowing piece on the "tranquillity" lived by the majority upset only, "from time to time, when incidents which are generally provoked by extremists occur, greatly exaggerated by the Press.” Peace, disarmament and "the granting of political rights to women” were all notable successes produced during its first year of existence, and must have confused the regular reader of the paper in being the first, and only, pro- Second Republic piece in the paper's history (Irish Independent, 3-5-32; AGA, 3-5-32). Normal service was resumed, much to Tovar's obvious disgruntlement, when on 1 June the Independent published another editorial entitled "Spain moves toward anarchy" in which the inevitable conclusion was drawn that "the Government appears to be impotent to put an effective stop to the red menace that is pushing Spain to the brink of disaster" (Irish Independent, 1-6-32). Again Tovar was forced to intervene with yet another strongly worded letter which appeared on 3 June to "neutralise and possible negative effects such an article may have had." He wrote a point by point rebuttal of the "alarming view" given of conditions in Spain. There were "a small number of agitators of no importance" but overall the country was "enjoying a democratic and energetic regime.” With a deliberate snipe at his hosts Tovar commented, "The industrial crisis is felt with less intensity than in other countries" and "Spanish securities are going up” (Irish Independent, 3-6-32; AGA, 3-6-32).

The effort was to no avail. On the same day as his letter appeared, the Irish Independent announced that it would be publishing a series of reviews of life in Spain by its "Special Correspondent" who had just returned back to Ireland. Their tone was quickly established by the first account, 'A brilliant failure' which declared that Spain, like Russia, "is not quite European.” Poor railways, peoples of mixed blood, a growing discourtesy toward foreigners, laziness "work is looked on by most Spaniards as a nuisance to be avoided whenever possible," who were late to bed, and where now "the shops today are full of Russian books" (Irish Independent, 7-6-32). The follow up article examined military and agrarian reforms in a more considered manner and was even laudatory toward Azaña, for his "vision and moderation”, moving away from Socialist 
principles, essential if the likely civil war was to be avoided. Whilst there was, on the whole, too much reform, "An immense amount of work, mostly good, has been done since the revolution" but that "violent anti-clericalism and ill considered agrarian Socialism have weakened it” (Irish Independent, 14-6-32).

More letters were sent by Tovar to the Irish Independent's editor in November after another "Red Terrors of Spain" feature was published on 1 November. Tovar also monitored the reaction within Ireland to the Catalan Autonomy Statute which was summed up in the Irish Times as being equivalent in power to "one of our own County Councils" (4-10-32). The visit of the Bishops of Madrid and Barcelona alongside 300 Spanish delegates and their behaviour at the Eucharistic Congress in Dublin in June were reported to Madrid, as was the participation of various Basque sportsmen under the auspices of Juventud Vasca (Basque Youth) who sang Basque songs on Irish radio. The Cervantes Conference held at Trinity in November was also mentioned as having been a success in promoting Spanish and Irish relations.

Matters of the economy as a result of the worsening trade and diplomatic relations with Britain as a result of the economic war, became more of a feature of Tovar's correspondence. He was convinced that in its current transitional state and given worsening economic conditions, "it will be possible for more favourable conditions to intensify commercial relations between Spain and Ireland.” The trade agreement between Ireland and Spain, agreed in principle in 1924 was still in abeyance but it did give Spain preferred country status which could be exploited. Issues surrounding Spanish fishermen in Irish waters were felt to be a possible obstruction and certainly by the beginning of 1933 their economic threat was perceived as a more tangible danger to Ireland than Spanish political reds (AGA 11727, 3-1-33). This was one of his last reports as on 6 March Tovar was obliged to pen a "defence of his administrative and personal" record in Dublin stating he had done his best to provide a detailed account of the political developments in Ireland, "so volatile in recent times" (AGA 54/11727, 6-333).

The potential for new trade links had become the main focal point of Tovar's final Dublin report on 18 March 1933. The potential for orange and tomato exports, as well as eggs, dairy products, leather goods, canned fish and construction material was huge and would be facilitated by direct shipping, not via Liverpool as was then the case. Without wishing to do anything to damage overall diplomatic relations with Britain, the Spanish Republican authorities were prepared to use their historical association with Ireland and her "current tariff war with Britain" to improve their trading balance and generate much needed income (AGA 11727). ). In 1933 Irish-Spanish trade was then $£ 726,000$ in Spain's favour, mainly from the Irish importation of wine, but it was hoped new sectors would follow to counter the slump felt by the consequences of the depression in established markets. Tovar's successors (Ranero Rivas March 1933-October 1934, and Plácido Alvarez Buylla) spent much of the next couple of years ensuring the ratification of a preferential trade treaty with Ireland which came into effect on 21 June 1934 and was followed by a supplementary agreement regarding the export of eggs (Kennedy, 2008: 195). The negotiations were often fraught, with the Spanish representative in Dublin frequently accusing his Irish counterparts, most notably Permanent Secretary Joseph Walshe of "deliberately undervaluing trade figures to promote their own interests." The Irish request for parity of trade was impossible, he argued, "given that Ireland has nothing to trade” (AGA 35/11728, 25-4-34).

Despite the disagreements the trade link did facilitate closer diplomatic ties between the two nations as the Spanish Consulate was raised to a Legation in February 1935 . The formal presentation of credentials by the new charges de affairs, Álvaro de Aguilar, who took up his post in September 1935 was extensively covered in the Irish press and followed in June by the Irish Government's appointment of Leopold Kearney as Irish minister plenipotentiary to Spain on 23 June 1935, significantly extending Ireland's overseas diplomatic representation. Minister of State Walshe wrote to the Spanish Foreign Ministry on 25 February 1935 stating that he was sure that this decision "will be a first step towards the revival of former close relations between our two countries" (AGA 34/35/11728). On the day after his appointment, Alvaro de Aguilar reported that Eamonn de Valera had visited the Legation 
expressing thanks "for the elevation of the diplomatic status" and of his desire "for developing the economic ties and general awareness of events in Spain" (AGA 11728, 20-12-35).

Tovar's replacement Francisco Ranero y Rivas first report entitled "Report on anticommunist demonstrations" seemed to set a new tone on the Spanish perspective of events in Ireland. He approved of Irish Government measures against those forces rallied against "the peace and tranquillity offered by the current legal framework, so evident in all countries.”(AGA, 54/11727, 31-3-33) Yet on 5 May 1933 he responded to the request made by Madrid on 16-3-33 regarding the political parties and political situation in Ireland by being extremely very critical of de Valera and his "political opportunism." As for attitudes toward Spain he concluded, "because of the continued influence of the Church on Irish society there exits, overall, a marked tendency against Spain and the Republic" where the majority of Irish opinion remained to be convinced about the advantages of the Republican constitution. For much of 1934, when not involved in negotiating the bilateral trade agreement, Ranero y Rivas occupied his reports analysing the political career of Eoin O'Duffy and his fascistic United Ireland and Blueshirt movement making allusions to but no direct references to Gil Robles organised rallies in Spain at the time (See reports 2-8-33, 14-833, 21-8-33, 4-9-33, 11-9-33, 13-10-33, 7-3-34 all from AGA, C54/11727).

Tovar's replacement Francisco Ranero y Rivas first report entitled "Report on anticommunist demonstrations" seemed to set a new tone on the Spanish perspective of events in Ireland. He approved of Irish Government measures against those forces rallied against "the peace and tranquillity offered by the current legal framework, so evident in all countries” (AGA 54/11727). Yet on 5 May 1933 he responded to the request made by Madrid on 16-3-33 regarding the political parties and political situation in Ireland by being extremely very critical of de Valera and his "political opportunism." As for attitudes toward Spain he concluded, "because of the continued influence of the Church on Irish society there exits, overall, a marked tendency against Spain and the Republic" where the majority of Irish opinion remained to be convinced about the advantages of the Republican constitution. For much of 1934, when not involved in negotiating the bilateral trade agreement, Ranero y Rivas occupied his reports analysing the political career of Eoin O'Duffy and his fascistic United Ireland and Blueshirt movement making allusions to but no direct references to Gil Robles organised rallies in Spain at the time (See reports 11727, 2-8-33, 14-8-33, 21-8-33, 4-9-33, 11-9-33, 13-10-33, 7-3-34, all from AGA, C54/11727).

From the diplomatic perspective, the mood toward Spain seemed to mellow officially at least in the light of the trade agreement. As Rivas' successor Plácido Alvarez Buylla noted in his summary on 19 December 1934 articles in praise of Spain and the help "she had always given Ireland in difficult times" multiplied in the newspapers on the occasion of death of a Mr O’Doherty, master of the College of Irish noblemen, linked to the Flight of the Earls. The new Consul begged Madrid's indulgence for mentioning this adding, "it is not an irrelevance because it is so rare to read or hear any praise regarding Spain” (AGA, 19-12-34).

A shared history, religion, but more relevant in the context of the early 1930s, the conflicting opinions within Ireland over the role of republicanism and the state, meant that the issue of Spain was very much prevalent in Irish society, long before the official status of that relationship caught up. The awareness of what was happening in Spain and the struggles of the II Republic facilitated the development and consolidation of Irish-Spanish diplomatic ties, which were not exclusively motivated by trade. The coverage of elections, attempted coups, closure of religious schools and orders, and very often partisan analysis of these measures in the Irish Independent, Times and Irish Press meant that Spain's political experience in part reflected and fuelled the debate in Ireland. The Spanish, red, experiment with republicanism was officially and publicly tolerated by Irish politicians who at best remained neutral, but who unofficially, in private, had no or little sympathy for the social revolution being conducted on the Iberian peninsula. As 1933 ended the prevailing attitude in Ireland toward Spain was the one held by Joseph Walshe himself who was much more favourably disposed to the CEDA and Catholic Church's attempts to return order to Spain. 


\title{
Works Cited
}

Egido Léon, Ángeles. 2000. "La dimensión internacional de la segunda república: un proyecto en el crisol” in Rosa M. Pardo, Javier Tusell, Juan Avilés (eds.) La política exterior de España en el siglo XX, Madrid: Biblioteca Nueva, 189-220.

Horgan, John. 2001 Irish Media: A Critical History since 1922, London: Routledge.

Jaspe, Álvaro. 2008. “Cautela, seguir mudo.” Madrid's Diplomatic Response to the Emergence of the Irish Free State 1918-1931, Estudios Irlandeses 3: 121-131, http://www.estudiosirlandeses.org/Issue3/Issue3Pdfs/pdfSAlvaroJaspe.pdf

Kennedy, Michael. 2008. "Leopold Kearney and Irish-Spanish diplomatic relations, 1935-1936" in Downey, Declan and Julio Crespo (eds.) Spanish Irish Relations Through the Ages, Dublin: Four Courts, 189-211.

\section{Unpublished material}

(AGA) Archivo General de la Administración, Alcala de Henares, Sección de Asuntos Exteriores, Ministerio de Asuntos Exteriores

\section{Newspapers and Journals}

\author{
Anglo-Celt \\ Connacht Tribune \\ Irish Independent \\ Irish Press \\ Sunday Independent \\ Southern Star
}

Received 6 February 2010 Revised version 29 September 2010

\begin{abstract}
Alvaro Jaspe is Lecturer in Spanish and Head of Hispanic Studies at the Magee Campus of the University of Ulster in Derry. This article is the latest in a series of studies conducted on the relationship between Spain and Ireland in the twentieth century. He has also written on Galicia and the Spanish Civil War.
\end{abstract}

